\title{
Nietzsche: proposições acerca de uma história genealógica e afirmadora da vida
}

\section{Nietzsche: Propositions about a genealogical and life-affirming history}

\author{
Raylane Marques Sousa \\ marques.raylane@gmail.com \\ Mestre em História \\ Universidade Federal de Minas Gerais \\ Rua Doutor Pergentino Maia, 1448, Messejana \\ 60840-045 - Fortaleza - Ceará \\ Brasil \\ Eduardo Ferreira Chagas \\ ef.chagas@uol.com.br \\ Professor Associado \\ Bolsista do CNPq \\ Universidade Federal do Ceará, Departamento de Filosofia \\ Rua Abdenago Rocha Lima, s/n, Campus do Pici \\ 60455-320 - Fortaleza - Ceará \\ Brasil
}

\section{Resumo}

O objetivo de nosso artigo orienta-se com base em duas linhas temáticas de investigação. A primeira delas ocupa-se com a crítica de Nietzsche à filologia clássica e, em alternativa, a criação de uma filologia das surpresas. A segunda linha focaliza a crítica de Nietzsche à genealogia clássica e aos genealogistas ingleses e, em alternativa, a proposição daquilo que, em nossos próprios termos, denominamos de "história genealógica e afirmadora da vida". No que diz respeito a esse ponto em específico, deter-nos-emos fundamentalmente em sua obra Genealogia da moral (1887), sobretudo por entendermos que na mesma estão depositadas as chaves interpretativas de seu pensamento genealógico.

\section{Palavras-chave}

História; Filologia; Genealogia.

\begin{abstract}
This article is guided by two basic lines of investigation. The first one deals with Nietzsche's critique of classical philology and, alternatively, the creation of a philology of surprises. The second line focuses on Nietzsche's criticism of classical genealogy and English genealogists and, alternatively, on the proposition of what we call - according to our terms - a 'genealogical and life-affirming history'. Regarding this point, we shall dwell fundamentally on his work On the Genealogy of Morality (1887), since it is our understanding, above everything else, that it holds the keys to the interpretation of his genealogical thought.
\end{abstract}

Keywords

History; Philology; Genealogy. 
Nietzsche é um filósofo intempestivo, como atesta o próprio título das suas quatro Considerações Intempestivas, mas é, especialmente, em sua II Consideração Intempestiva (1874) que ele revela a sua intencionalidade. Nessa obra de juventude, Nietzsche apresenta-se como filólogo e aponta como pretende atuar em seu presente. Ele considera que o sentido da sua formação como filólogo é este mesmo: "agir contra a sua época, sobre sua época e em benefício de uma época vindoura" (NIETZSCHE 2005, p. 70). Também em Ecce homo (1888), ele proclama a sua intempestividade, tanto no que diz respeito à sua profunda crítica à racionalidade moderna quanto à sua oposição ao clima triunfante que caracteriza o seu próprio tempo. A este respeito, ele afirma: "Eu mesmo não sou ainda atual; alguns nascem póstumos" (NIETZSCHE 2007, p. 67). Nesse sentido, fica evidente que Nietzsche é um pensador preocupado com seu presente, porém oposto ao seu modo de ser e de pensar, e isso para proveito de uma época posterior.

Em que contexto Nietzsche é um filósofo intempestivo? O que significa, pois, ser um pensador intempestivo? Como pontua Céline Denat, intempestivo não é ser "intemporal", não é ser abstraído do tempo presente. Intempestivo quer dizer não concordar com o "espírito do seu tempo". O pensador intempestivo é aquele que toma certa distância de sua época, e tal distância não diz respeito à temporalidade ou à historicidade, mas refere-se apenas ao seu tempo, isto é, à atualidade e aos valores que lhe são próprios. O pensador intempestivo tem a capacidade de pensar de outro modo, de enxergar a partir de outros ângulos e de se desprender da sua cultura; ele não permanece preso ao que a sua época louva e se orgulha - a cultura, os valores, as conquistas militares. Ele é capaz de estar em sua época e adotar pontos de vista de outras épocas, de outros lugares, de outros povos, de outras culturas, e isso em benefício de um tempo e de uma cultura futura (DENAT 2010).

Citemos, portanto, algumas das principais razões que fazem de Nietzsche um pensador intempestivo:

Em primeiro lugar, Nietzsche critica o método da filologia clássica, mas toma-o emprestado e aperfeiçoa-o à sua maneira, tornando-o capaz de perceber diferenças mais sutis, alterações e variações mais complexas, tanto de épocas passadas quanto de épocas mais próximas, que aquelas concebidas, normalmente, pelo método filológico tradicional.

Em segundo lugar, e essa é nossa consideração pessoal, a principal razão que atesta a intempestividade do pensamento de Nietzsche é a que ele critica a genealogia clássica e, em particular, os genealogistas ingleses, e a partir de então, cria um novo "método" e institui uma historicidade autêntica, a história genealógica crítica, questão que trataremos nas páginas seguintes.

A partir dessas considerações iniciais, explicaremos, então, o objetivo de nosso artigo, o qual se orienta com base em duas linhas temáticas de investigação, a saber:

1. A crítica de Nietzsche à filologia clássica e, em alternativa, a criação de uma filologia das surpresas. Nossa abordagem destacará, nesse primeiro ponto, a crítica de Nietzsche ao método da filologia clássica e, como solução 
para os problemas que ele encara no que tange aos limites de investigação do método filológico tradicional, demonstraremos passo a passo a formulação do seu método filológico das surpresas.

2. A crítica de Nietzsche à genealogia clássica e aos genealogistas ingleses e, em alternativa, a proposição daquilo que, em nossos próprios termos, denominamos de "história genealógica e afirmadora da vida". Nossa análise enfatizará, nesse segundo ponto, a crítica de Nietzsche à abordagem genealógica clássica e ao modo como os genealogistas ingleses tratam os valores morais, e, como saída para os problemas que ele detecta no que se refere à abordagem genealógica tradicional, demonstraremos a sua abertura para um tipo de história genealógico e afirmador da vida. No que concerne a esse último ponto em específico, deter-nos-emos em sua obra Genealogia da moral (1887), sobretudo por entendermos que na mesma estão as chaves interpretativas de seu pensamento genealógico.

\section{Da filologia clássica à filologia das surpresas}

Em Aurora (1886), Nietzsche escreve como ele gostaria de ser lido. No prefácio a esse texto, o filósofo alemão afirma que quer ser lido com lentidão, paciência e profundidade. Segundo ele,

[...] Este prefácio chega tarde, mas não demasiado tarde; que importam, por fim, cinco ou seis anos? Tal livro e tal problema não têm pressa; e, além disso, nós somos amigos do 'lento', eu, assim como o meu livro. Não fui, em vão, filólogo, e ainda o sou talvez. Filólogo quer dizer mestre na leitura lenta, e que acaba por escrever lentamente. Mas não é que seja isto somente um hábito em mim, é um prazer mau, um prazer maligno talvez? Não escrever outra coisa senão o que poderia desesperar aos homens que 'se apressam'. Pois a filologia é essa arte venerável que antes de tudo exige uma coisa de seus admiradores: manter-se à parte, ir devagar, tornar-se silencioso, tornar-se lento; como uma arte de ourivesaria e uma perícia no conhecimento da 'palavra', uma arte que exige um trabalho delicado e que não realiza nada se não trabalhamos com lentidão. [...] Esta arte, a que me refiro, não termina facilmente nada; ensina a ler 'bem', quer dizer, a ler de trás para frente, a ler devagar, com profundidade, com pensamentos íntimos, com dúvidas e precauções, com dedos e olhos delicados... Amigos pacientes, este livro somente pede leitores e filólogos perfeitos: 'aprendei' a ler-me bem (NIETZSCHE 2008, p. 14).

De acordo com Werner Stegmaier, Nietzsche teria aprendido a ler com cautela, vagareza e profundidade, procurando alcançar as sutis "nuances" do texto, isto é, aquilo que não foi conceitualizado, durante a sua formação como filólogo. A filologia o teria conduzido à arte de ler e escrever "bem", "sem pressa" e "com profundidade", de modo que essa mesma arte, a que ele foi iniciado durante a sua educação como filólogo, ele exigia ver também entre os seus comentadores e leitores. Para Stegmaier, a filologia de Nietzsche contrasta com uma forma de trabalho apressado e que quer terminar logo com tudo facilmente, de maneira que não sobra espaço para a emergência de surpresas. A filologia de Nietzsche é radicalmente o oposto disso, pois ela não quer terminar facilmente nada, ela não procura o definitivo, o decisivo, mas sim as "segundas intenções"; 
ela deixa as portas abertas para a chegada do novo, do inesperado. A filologia de Nietzsche é definitivamente diferente, porque exige do leitor "dedos e olhos delicados" (STEGMAIER 2013).

Ao apontar como gostaria que fossem os seus leitores, Nietzsche quer prepará-los para as "surpresas filológicas" (STEGMAIER 2013, p. 289) depositadas na sua Genealogia da moral (1887). Nesse texto de maturidade, como veremos no próximo ponto, Nietzsche põe sob questionamento pensamentos cristalizados, verdades essenciais, tidos até então como dados inquestionáveis. Com isso, Nietzsche quer mostrar aos seus leitores que os pensamentos e as verdades que eles acreditam não poder viver sem eles são, na realidade, pensamentos e verdades dispensáveis e transitórias. No entanto, como afirma Stegmaier, Nietzsche não quer mostrar as suas "surpresas filológicas" a partir do campo estreito da ciência filológica clássica. De certo modo, Nietzsche deixa de lado os elementos científicos, as teses e leis científicas, os argumentos ordenados de forma lógica e hierárquica, a erudição e o pedantismo do cientista, as citações, as notas e as terminologias fixas. Ele pretende fazer isso a partir de sua própria "filosofia filológica", isto é, de uma "filosofia das surpresas" (STEGMAIER 2013).

Nietzsche quer levar o seu leitor a questionar e a interrogar certas verdades tomadas como indispensáveis para a sua sobrevivência. Para isso, ele exige que o seu leitor tenha coragem e seja como um animal de rapina. Na sua obra Ecce homo (1888), que é uma espécie de genealogia sobre ele mesmo, Nietzsche traça um perfil do seu "leitor perfeito": "Se tento afigurar-me o tipo de um leitor perfeito, faço-o sempre um monstro de coragem e de curiosidade, com algo mais de agilidade, astúcia e circunspecção: um aventureiro e explorador nato" (NIETZSCHE 2007, p. 71). Com isso, Nietzsche afirma que o seu leitor perfeito deve ser esperto e aventureiro, isto é, que não tem medo de descer aos abismos do pensamento, que não tem receio de conhecer as novidades do pensamento, que não se poupa nunca, mas, antes, corajosamente, renuncia às estabilidades, às atemporalidades e à metafísica (STEGMAIER 2013).

O Nietzsche da maturidade, por meio de sua "filosofia filológica", enfatiza a temporalidade e a transitoriedade de todas as coisas e de todo pensamento a respeito das coisas. Nessa fase de seu pensamento, Nietzsche é um claro opositor da metafísica e dos pressupostos essenciais subjacentes a ela. Em sua Genealogia da moral (1887), ele claramente apresenta a base da sua "filosofia filológica". No Prefácio a esse texto, Nietzsche trata de expor que não existe nenhum "puro" sujeito do filosofar com um "puro" autoconhecimento. Nesse sentido, ele afirma:

Nós, homens do conhecimento, não nos conhecemos; de nós mesmos desconhecidos - e não sem motivo. Nunca nos procuramos: como poderia acontecer que um dia nos encontrássemos? Com razão alguém disse: 'onde estiver o teu tesouro, estará também teu coração' Nosso tesouro está onde estão as colmeias do nosso entendimento. Estamos sempre a caminho delas, sendo por natureza criaturas aladas e coletoras do mel do espírito, tendo no coração apenas um propósito - levar algo 'para casa'. Quanto ao mais da vida, as chamadas 'vivências', qual de nós pode leválas a sério? Ou ter tempo para elas? Nas experiências presentes, receio, 
estamos sempre 'ausentes': nelas não temos o nosso coração - para elas não temos ouvidos. [...] Continuamos necessariamente estranhos a nós mesmos, não nos compreendemos, temos que nos mal entender, a nós se aplicará para sempre a frase: 'Cada qual é o mais distante de si mesmo' - para nós somos 'homens do desconhecimento' (NIETZSCHE 1998, p. 7-8).

Nietzsche afirma, com isso, a temporalidade e a transitoriedade de todo pensamento. Segundo ele, na sua busca constante por um "puro" sujeito do filosofar com um "puro" autoconhecimento, os homens do conhecimento ignoram a si mesmos, tornam-se desconhecedores acerca de si mesmos, pois, ao buscarem apenas acumular conhecimento, eles deixam de lado as experiências que envolvem todo conhecimento. No entanto, quando os homens do conhecimento pensam sobre tais experiências, na realidade, refletem sobre si mesmos, conhecem e interpretam a si mesmos. Para Nietzsche, nisso consiste a novidade de seu pensamento filológico, a saber, poder descobrir-se e conhecerse a si mesmo, poder autocriticar-se e autossuperar-se, sem precisar recorrer a uma força suprassensível, essencial, exterior a si mesmo.

Qual é a filologia que Nietzsche reivindica e a qual tipo de ciência filológica ele se opõe? O que Nietzsche compreende então por filologia? Conforme Nietzsche, uma filologia compatível com o seu filosofar não pode ser atemporal, não pode basear-se em dados a priori e metafísicos. Nietzsche compreende "filologia" no padrão da Escola Ritschl, isto é, como distanciar-se do texto - e filosoficamente dos fatos empíricos - e, mais ainda, como distanciar-se das interpretações que se afirmam involuntariamente (STEGMAIER 2013). Nesse sentido, a filologia a que Nietzsche se opõe é aquela feita por Ulrich von Wilamowitz-Möllendorf, aquela que se restringe à pesquisa e à análise de fragmentos isolados de textos antigos. Nietzsche observa nela apenas um trabalho cego, de toupeira, técnico e, por isso, incapaz de descobrir um ponto de vista novo sobre uma dada questão e de apreender na totalidade o seu objeto de estudo (MACHADO 2005; WOTLING 2013).

Na obra $O$ anticristo (1888), Nietzsche então define o que ele compreende por filologia:

Eu entendo aqui por filologia, em sentido geral, a arte de ler bem, de saber distinguir os fatos, sem os falsear com interpretações, sem perder, no desejo de compreender, a precaução, a paciência e a delicadeza; a filologia como ceticismo na interpretação: trata-se de livros ou de notícias de jornais, de destinos ou de fatos meteorológicos, para não falar da "salvação da alma [...]" (NIETZSCHE 2000, p. 91).

No entendimento de Nietzsche, a filologia não pode se apegar a textos considerados canônicos, muito embora não os recuse totalmente. Na filologia nietzschiana, os textos chamados canônicos não são, na realidade, canônicos, mas se referem a determinados textos que se têm em vista. A filologia nietzschiana não elabora antecipadamente as regras de seu método, porém responde às novas descobertas com métodos inusitados. Com isso, a filologia 
nietzschiana não está completamente livre de erros diante dos textos, pelo contrário, ela assume que pode, sim, cometer equívocos, mas que tais equívocos podem ser inconscientes, pois as regras do seu método não são formuladas aprioristicamente (STEGMAIER 2013).

De acordo com Stegmaier, um pré-requisito para a filologia nietzschiana é ser um "bom amigo", isto é, ser "amigo" das suas "palavras". Nietzsche afirma, em Além do bem e do mal (1886), que aquele que é um bom amigo já conhece o seu amigo e já se acostumou com a sua amizade, o que o leva a tratá-lo sem distanciamento e sem reservas. Para Nietzsche, isso é bom, mas também é um risco. Os bons amigos podem, por causa da comodidade e da falta de distanciamento de tal amizade, não compreender corretamente o seu amigo ou tratá-lo com indolência (NIETZSCHE 1992). No seu caso, Nietzsche sugere que os seus "bons amigos" leiam os seus textos com vontade e confiança próprio a todo bom amigo, mas sempre desconfiando e suspeitando da amizade que ele Ihes oferece (STEGMAIER 2013). A filologia de Nietzsche é, portanto, uma filologia da distância e da desconfiança; é uma filologia da suspeita. É essa forma de filologia que Nietzsche reivindica que seja feita em seu tempo e que ele mesmo aplica em sua Genealogia da moral (1887).

Na mesma linha de pensamento de Werner Stegmaier está Patrick Wotling. Segundo este, a filologia que Nietzsche reivindica tem um alcance metodológico mais ousado. Em sua concepção de filologia, Nietzsche substitui o conceito de "explicação" pelo conceito de "interpretação". Nietzsche recusa o conceito de explicação dos metafísicos porque tal conceito pressupõe a ideia de "verdade" absoluta. Para Nietzsche, a noção de verdade dos metafísicos refere-se à questão do sentido do texto em termos idealistas, ou seja, dualistas e essencialistas. Aborda-se o sentido do texto de forma dualista ao considerar a existência de dois valores indispensáveis e opostos, quais sejam, verdade e falsidade, de forma que de cada texto só é possível extrair uma única interpretação considerada verdadeira; por outro lado, aborda-se o sentido do texto de forma essencialista ao considerá-lo como contendo um sentido absoluto e imutável. Segundo Wotling, Nietzsche, desde muito cedo, recusa esse tipo dualista e idealista de análise e decifração dos textos filológicos. Nietzsche exige, portanto, que essa forma de tratamento dos textos filológicos feita até então seja substituída por uma forma de tratamento mais honesta e justa (WOTLING 2013).

De acordo com Wotling, Nietzsche utiliza a metáfora filológica para denunciar três grandes equívocos metodológicos que os filósofos metafísicos cometem frequentemente. A primeira infração metodológica que Nietzsche quer denunciar tem a ver com a forma desrespeitosa com que os filósofos tratam o texto (filológico, da natureza, do passado, etc.). Segundo Nietzsche, eles manipulam ou falsificam o estatuto do texto tendo em vista fins partidários. Nietzsche quer denunciar esses filósofos que, desprovidos de probidade em relação ao sentido do texto, aceitam a falsificação da realidade desde que o resultado esteja de acordo com os seus preconceitos.

A segunda infração que Nietzsche quer denunciar tem a ver com a confusão que tais filósofos fazem entre o texto e a sua interpretação, o que acaba apagando 
as diferenças entre os dois. Nietzsche considera que, na filologia, no que diz respeito ao plano metodológico, o texto sempre tem prioridade em relação à sua interpretação. Para Nietzsche, por exemplo, as ciências exatas, em específico a física, sempre cometem essa confusão. Nesse caso, a física sempre confunde o texto original, isto é, os fenômenos naturais, com a sua interpretação. Ela sempre impõe um texto segundo sobre o texto primeiro, de modo que o texto segundo se confunde com o texto primeiro e este acaba desaparecendo. Nesse sentido, o texto segundo acaba se tornando uma explicação destinada a elucidar e, por fim, substituir o texto primeiro.

A terceira infração metodológica que Nietzsche quer denunciar tem a ver com a interpretação "mentirosa" e "delirante" que os cristãos, por exemplo, fazem do texto bíblico. Este último equívoco, segundo Nietzsche, consiste em interpretar um texto já munido previamente de uma interpretação, que será, seguidamente, posta no lugar do texto a ser interpretado. Com isso, Nietzsche quer chamar atenção para duas questões: a imposição de interpretações e o valor de tais interpretações. Com efeito, Nietzsche almeja eliminar o acréscimo de sentido que os cristãos, os padres, os filósofos e até mesmo os filólogos injetam no texto. Para ele, tal excesso de sentido é uma interpretação mentirosa do texto, interpretação essa que pode falsificá-lo e, por fim, corrompê-lo completamente. Esses são os falsos procedimentos filológicos que Nietzsche visa denunciar, estabelecendo com isso uma verdadeira caça aos palimpsestos (WOTLING 2013).

Nietzsche pretende, na realidade, a partir dessas denúncias dos erros praticados pela filologia tradicional, preparar os filósofos, os filólogos, os leitores, em geral, para o entendimento de um fenômeno sobre o qual ele se debruçará em sua Genealogia da moral (1887), a saber: a criação e a imposição dos valores morais. Nesse texto, Nietzsche quer, entre outras coisas, eliminar as interpretações que se interpõem à leitura e que impedem que o texto original da moralidade, que não é outra coisa senão submissão cega aos costumes, seja então lido e conhecido.

Com isso, Nietzsche não quer, no entanto, também impor ao texto um excedente de sentido, tal como fizeram os filólogos tradicionais. Ele está, pelo contrário, ciente de que seu primeiro dever metodológico é, portanto, não corromper o texto que ele interpretará. Tanto é dessa forma que ele mesmo fala, em um trecho do seu livro $O$ anticristo (1888), já mencionado aqui, que ele entende por filologia "a arte de ler bem", ou melhor, a arte de ler um texto com coragem, lentidão e paciência, sem desrespeitá-lo e sem corrompê-lo com explicações falsas e interpretações mentirosas. Portanto, por meio de seu procedimento filológico, Nietzsche tem o cuidado de interpretar o texto original sem fazer oposição à sua teoria de interpretação infinita do texto e sem colocar em questão a sua crítica à noção de verdade absoluta e à noção dualista da explicação metafísica. Nesse sentido, a filologia nietzschiana apresenta-se como um verdadeiro trabalho de interpretação, pois ela pressupõe um enfrentamento com o texto original da moralidade (WOTLING 2013). 


\section{Proposições acerca de uma história genealógica e afirmadora da vida}

Em Nietzsche, a genealogia e a história, Michel Foucault começa dizendo que a genealogia de Nietzsche é cinza e rigorosa. Ela é cinza porque trabalha com a coisa documentada, o efetivamente constatável, o que realmente sucedeu; e é rigorosa porque é um procedimento minucioso, pormenorizado e metódico. Nesse artigo, Foucault demonstra a diferença existente entre gênese e genealogia na obra de Nietzsche. Para o filósofo francês, ao passo que o procedimento genético perscruta a "origem" de todas as coisas, pressupondo com isso que elas teriam uma essência, o genealógico visa fazer uma crítica à noção de essência, questionando sobre o valor que se atribui às coisas ao longo do tempo. Com isso, Foucault demonstra que entende a genealogia de Nietzsche como exame da proveniência e história das emergências. Para Foucault, a proveniência (Herkunft) não remete ao fundamento de algo, não sinaliza para a igualdade, para a continuidade, mas, antes, busca encontrar as diferenças e as heterogeneidades, as fissuras e as brechas, os desvios e os acidentes de percurso, sob aquilo que se tem como linear, homogêneo, como conforme a si mesmo. A emergência (Entstehung), por outro lado, não remete aos termos finais de um processo, mas, antes, ao "princípio e à lei singular de um aparecimento" (FOUCAULT 2015, p. 65). Ao se questionar sobre a emergência de determinadas normas, por exemplo, não se almeja uma explicação das causas que as teriam feito surgir, mas a revelação do ponto de seu surgimento enquanto norma (FOUCAULT 2015; MARTON 2009).

Os moralistas ingleses organizaram, segundo Foucault, toda a história da moral de maneira linear e contínua, classificando, ordenando e mostrando somente o que, para eles, era útil de tal história. Dessa forma, a história da moral descrita pelos ingleses ocultava o conflito de sentimentos, disfarçava a luta em torno do estabelecimento dos significados das palavras, escondia as intenções e as direções dos desejos. A genealogia de Nietzsche aparece como oposição a essa história da moral dos ingleses. A sua principal característica é a exigência de um saber demorado, lento, vagaroso. O seu trabalho é capturar a singularidade dos acontecimentos, deixando de lado a utilidade que tais acontecimentos possam ter. $O$ instrumento genealógico de Nietzsche é radicalmente diferente porque ele procura história lá onde os moralistas ingleses jamais pensaram que poderia existir, como nos sentimentos, no amor, no ódio, na dor, na compaixão, no ressentimento. O método genealógico de Nietzsche não tem a intenção de capturar a evolução desses sentimentos ao longo do tempo, mas quer perceber, historicamente, como se estabeleceram as lacunas, ou melhor, os momentos nos quais esses sentimentos foram ocultados, esquecidos ou até mesmo mudaram de sentido. Desse modo, afirma Foucault: "A genealogia não pretende recuar no tempo para restabelecer uma grande continuidade para além da dispersão do esquecimento; sua tarefa não é a de mostrar que o passado ainda está lá, bem vivo no presente, animando-o ainda em segredo" (FOUCAULT 2015, p. 62-63). O procedimento genealógico de Nietzsche é, ao contrário, um método histórico-crítico que pretende fazer a investigação e a avaliação da criação, do nascimento, da proveniência e do estabelecimento do significado dos conceitos "bom" e "mau" e "bom" e "ruim" ao longo do tempo (FOUCAULT 2015). 
Gilles Deleuze, em seu livro Nietzsche e a Filosofia, principalmente nas três primeiras partes do capítulo "O trágico", ao comentar sobre a obra Genealogia da moral (1887), afirma que Nietzsche, ao instaurar o seu procedimento genealógico, faz uma espécie de "inversão crítica", quer dizer, ele deixa de lado a noção de "origem" e torna operatórias as noções de "sentido" e de "valor", para empreender uma "crítica total", para fazer uma "filosofia a marteladas" (DELEUZE 1976, p. 4). É, pois, a partir desses dois conceitos que Nietzsche coloca sob suspeita o valor dos valores (morais, religiosos, científico, filosóficos, etc.), a apreciação da qual deriva o valor deles e as condições de sua criação, de sua modificação ao longo do tempo e de seu estabelecimento. Com isso, Nietzsche deseja acabar com a atribuição de valor e destruir, por conseguinte, a manutenção das avaliações.

A apreciação do valor dos valores é, segundo Deleuze, o elemento diferencial dos valores então estabelecidos, pois é tanto elemento crítico quanto elemento criador. As apreciações acerca do valor dos valores não são valores, mas expressam o modo de ser, de viver e de agir dos que apreciam, valendo para eles como ponto de partida para o julgamento de tais valores. Nesse sentido, existem valores que só podemos compreender se avaliarmos "baixamente", a partir de um modo de viver, de pensar e de entender "baixamente". Assim, afirma o referido comentador, para Nietzsche, os opostos alto e baixo, nobre e vil, não são propriamente valores, mas apreciações das quais advém o valor dos valores (DELEUZE 1976).

De acordo ainda com Deleuze, quando Nietzsche introduziu as noções de sentido e de valor em sua filosofia, ele operou uma "inversão crítica" pelo fato de esses dois conceitos não considerarem o valor como algo efetivo, dado, mas suspeitarem do valor dos valores morais. Desse modo, a filosofia dos valores de Nietzsche passou a operar dois movimentos inseparáveis: de um lado, relacionar todas as coisas e a sua origem a valores; de outro, relacionar esses valores à sua origem e às avaliações que os instituíram como valores. Com isso, Nietzsche opôs-se principalmente aos moralistas ingleses, aos eruditos e aos utilitaristas, que se esquivaram de fazer uma crítica séria dos valores ou que criticaram as coisas em nome de valores instituídos, cristalizados e tidos como resultantes de fatos presunçosamente objetivos. Nietzsche critica tanto a ideia de fundamento, que não relaciona os valores à sua origem, quanto a ideia de que os valores estão relacionados a uma origem sem interesses, isto é, indiferentes. Por meio da sua filosofia dos valores, Nietzsche prova que o problema dos valores é a sua criação e que a solução para tal problema está em discutir de onde derivam as avaliações que estabeleceram tais valores (DELEUZE 1976).

Com efeito, a mais reveladora reflexão de Nietzsche, na qual ele apresenta o seu novo conceito de genealogia, precisa a tarefa genealógica e se empenha em discutir a emergência, a evolução e o enraizamento dos valores morais no "palco dos acontecimentos", está na obra Genealogia da moral (1887), um escrito chocante e polêmico, como o próprio subtítulo da obra sugere. Nessa obra, Nietzsche replica discussões com o Dr. Paul Rée e com os genealogistas ingleses, rejeita o método empregado por estes para "reconstituir a gênese da 
moral", o utilitarismo inglês, e adota uma postura não de juiz ou de utilitarista, mas de filósofo genealogista, que busca mostrar que "as morais têm uma genealogia, o que significa dizer que elas têm uma ascendência e evoluem e não são ditadas a partir de uma instância superior por um legislador supremo e sobrehumano" (DANTO apud FONSECA 2007, p. 31). Assim, nessa obra, Nietzsche investiga a "origem" da moral e dos preconceitos morais, a fim de provar que ela não é eterna e que as suas leis, então tidas como constantes e invariáveis, não têm, de forma alguma, fundamento metafísico, transcendente. No entanto, para conseguir provar a "origem" histórica da moral e dos preconceitos morais, Nietzsche não pretende fazer como o iluminista, isto é, desnudar os véus que envolvem uma "origem" escondida, mas sim por meio de sua educação filológica e histórica, como ele mesmo faz questão de relembrar, empreender uma incursão ao passado para compreender as condições que engendraram a criação e a atribuição de valores a determinados valores e, só a partir de daí, desmistificar a "origem" de tais valores e as verdades que eles sustentam (FONSECA 2007).

Depois de explicar, no Prólogo à Genealogia da moral (1887), a perspectiva genealógica que ele pretende adotar para tratar a "origem" da moral e dos problemas morais, Nietzsche analisa, na primeira dissertação, os valores "bom" e "mau" e "bom" e "ruim" e como eles foram criados e instituídos pela maneira nobre e escrava de avaliar. Na segunda dissertação à referida obra, ele examina o modo de agir do homem de ressentimento, demonstrando como surgiram a "culpa", a "justiça", o "castigo", a "má consciência" e coisas afins. Feito isso, na terceira dissertação desta obra, ele reflete sobre a intervenção dos ressentidos na arte, na filosofia, na ciência e na religião, explicitando que todas elas buscam inspiração no ideal ascético. Nas três dissertações, ele submete a moral, o comportamento do homem de ressentimento e a sua produção ao exame genealógico, constatando com isso que se trata de uma doença perniciosa e maléfica (MARTON 2014).

No Prólogo da obra Genealogia da moral (1887), Nietzsche escreve claramente a que ela veio e qual a sua nova exigência:

\begin{abstract}
Necessitamos de uma crítica dos valores morais, o próprio valor desses valores deverá ser colocado em questão - para isto é necessário um conhecimento das condições e circunstâncias nas quais nasceram, sob as quais se desenvolveram e se modificaram (moral como consequência, como sintoma, máscara, tartufice, doença, mal-entendido; mas também moral como causa, medicamento estimulante, inibição, veneno), um conhecimento tal como até hoje nunca existiu nem foi desejado (NIETZSCHE 1998, p. 12, grifos do autor).
\end{abstract}

Na história da moral, nunca houve, segundo Nietzsche, um questionamento sequer acerca de se atribuir ao "bom" valor mais elevado que ao "mau". Nesse sentido, ele pergunta: e se o mau tivesse valor mais alto que o bom? E se no bom houvesse uma droga capaz de deixar o presente dependente do futuro? (NIETZSCHE 1998). Na percepção de Nietzsche, os moralistas ingleses nunca pensaram em tais questionamentos porque nunca se dispuseram a percorrer, de fato, a extensa região da moral, da moral que efetivamente existiu e se 
viveu. Eles sequer cogitaram direcionar novos olhares e novas perguntas para o subterrâneo e os recônditos dessa longínqua região porque, em nenhum momento, em todo o seu trabalho como genealogistas, pensaram valer a pena levar realmente a sério os problemas da moral.

Na visão de Nietzsche, em momento algum na história da moral, os pares de valores "bom" e "mau" e "bom" e "ruim" foram colocados sob suspeita e interrogados, para que então o seu valor e as suas circunstâncias de criação fossem conhecidos, porque simplesmente "tomava-se o valor desses 'valores' como dado, como efetivo, como além de qualquer questionamento" (NIETZSCHE 1998, p. 12). Se o valor desses valores não foi colocado sob suspeita e desconfiança até o momento, é porque eles foram tomados como pressupostos intocáveis, como existentes desde sempre, isto é, eles foram instituídos e justificados num mundo além, eles foram anteriormente dados ora por Deus, ora pela natureza, ora pela razão. Ao serem postos em questão, entretanto, esses valores se mostraram completamente "humanos, demasiado humanos", isto é, criações muito humanas (MARTON 2014; PASCHOAL 2000).

Tendo em vista que os valores são invenções humanas, Nietzsche queria que os estudiosos da moral se sensibilizassem e atentassem para a abertura de perspectiva que ele viu descortinar-se para ele e, da mesma forma, abraçassem outra maneira de pensar a crença na moral e nos valores morais. $E$, para isso, Nietzsche queria que eles se inquirissem a respeito das seguintes questões:

Sob que condições o homem inventou para si os juízos de valor 'bom' e 'mau'? E que valor eles têm? Obstruíram ou promoveram até agora o crescimento do homem? São indícios de miséria, empobrecimento, degeneração da vida? Ou, ao contrário, revela-se neles a plenitude, a força, a vontade da vida, sua coragem, sua certeza, seu futuro? (NIETZSCHE 1998, p. 9).

Segundo Vânia Dutra de Azeredo, em seu livro Nietzsche e a dissolução da moral, amparada principalmente em Deleuze, para Nietzsche, os estudiosos da moral, no que tange ao tratamento dos valores, sempre flutuaram entre aquilo que valeria em si e aquilo que valeria para a coletividade. Atribuir um valor a determinada coisa significa compreender que esse valor é algo dado, ele não pode ser colocado sob suspeita e, tampouco, pode ser interpretado a respeito da sua instituição enquanto valor. Esse valor tem validade em si mesmo e, nesse sentido, é inquestionável acerca de seu próprio valor. A autora ainda coloca que, para Nietzsche, apesar daquilo que vale em si divergir do valor como algo válido para todos, o ato de atribuir valor é oriundo de uma avaliação referida a todos, como também a recusa de questionar tais avaliações (AZEREDO 2000).

De acordo ainda com Azeredo, ao tecer essas críticas aos moralistas ingleses, o projeto de Nietzsche é justamente introduzir na filosofia os conceitos de "sentido" e de "valor", promover com isso a expulsão de fatos morais e afirmar a existência de uma apreciação moral dos fatos (AZEREDO 2000, p. 3435). Para a comentadora, se Nietzsche considera essa possibilidade, é porque ele sabe que existem os que interpretam e os que avaliam os fatos morais. Assim, 
a interpretação constitui-se como apresentação de uma perspectiva acerca dos fatos morais e a avaliação como instituição de um valor. Para empreender o exame dos valores morais, a fim de explicitar as suas circunstâncias de criação e de estabelecimento, a questão "Quem?" é fundamental. Em Nietzsche, a pergunta "Quem?" instaurou o procedimento genealógico como método orientador, o qual permitiu desnudar as condições de criação das avaliações e, dessa forma, estabelecer o valor dos próprios valores (AZEREDO 2000).

Na obra de Nietzsche, essa interrogação "Quem?" inevitavelmente sinaliza para o procedimento genealógico, que opera então um mergulho na região profunda e recôndita da moral não em busca do valor que se esconde por trás da avaliação, mas da avaliação que institui o valor dos valores morais. Essa é a alternância crítica que Nietzsche opera, pois ele tem o cuidado de não fazer do seu método genealógico apenas um instrumento para inventário e registro de valores dados ou ferramenta que critica as coisas a partir de valores dominantes, tido como verdadeiros. Nietzsche, pelo contrário, faz do seu método genealógico um instrumento de suspeita, que descredencia antigas posições de valor, que desmonta antigas criações de valor, as quais se tornaram dominantes e, ao logo do tempo, tornaram-se verdades petrificadas (AZEREDO 2000).

Para Nietzsche, os moralistas ingleses em tempo nenhum se perguntaram, como frisado, pelo valor dos valores morais, porque tinham como critério de avaliação a utilidade de tais valores, e não a criação de valor de tais valores. Nietzsche é severo e afirma que a avaliação dos moralistas ingleses também será posta sob suspeita, a fim de esclarecer questões como: quem toma a utilidade como critério de avaliação? O que quer aquele que toma a utilidade como critério de avaliação? Tendo em vista a falha dos moralistas ingleses de não atentarem, como dito, para a noção de valor dos valores e não se referirem à questão fundamental "Quem?", Nietzsche diz que a eles falta o espírito histórico e os acusa então de fazerem uma genealogia essencialmente a-histórica (NIETZSCHE 1998 , p. 18). Assim, embora sábios conhecedores, Nietzsche os classifica como "homens do desconhecimento" (NIETZSCHE 1998, p. 18), pois não compreendem a dimensão moral de todas as coisas e não entendem a genealogia como método que proporciona a sua compreensão. Nietzsche fala isso acerca dos moralistas ingleses porque ele observa que eles se esquivam de se questionarem sobre a criação de valor dos valores morais, procurando apenas debruçarem-se sobre determinado dado do conhecimento e analisá-lo de maneira superficial e rasteira. Para Nietzsche, ao agirem assim, os moralistas ingleses desconhecem a capacidade do homem de produzir interpretações, de fazer avaliações e, sobretudo, de criar valores. Sendo assim, é compreensível que Nietzsche os tenha denominado de "homens do desconhecimento" (AZEREDO 2000).

Em sua obra Genealogia da moral (1887), a questão principal que Nietzsche coloca em discussão é, portanto, o "valor da moral" (NIETZSCHE 1998, p. 11). Ele percebe que os instintos de abnegação, sacrifício e de compaixão, que, por exemplo, Schopenhauer tanto idealizou e divinizou, depreciam o homem e negam a própria vida, porquanto são "valores em si", que escondem a "vontade de nada", ou melhor, o niilismo (NIETZSCHE 1998). Nesse sentido, ele coloca 
também sob suspeita o valor da moral do altruísmo e da piedade que acomete a cultura europeia e que se encontra na base de toda a civilização ocidental, e então o interroga, para identificar e explicitar de qual "solo" o valor da moral proveio, de onde ele nasceu, como ele se desenvolveu, como ele se modificou e sob quais condições ele se enraizou. Nietzsche quer fazer uma crítica não apenas do valor da moral da abnegação e da piedade, mas de toda moral e de seu sentido valorativo. Para isso, ele sabe que precisa primeiro conhecer o valor da moral, como ele surgiu, como se metamorfoseou e se estabeleceu para, em seguida, fazer a crítica do valor dos valores morais. Tendo em vista a possibilidade do valor dos valores se metamorfosear e se disfarçar ao longo do tempo, o que dificulta a sua apreensão, compreensão e crítica, Nietzsche fala da moral como sendo consequência, sintoma, máscara, mal-entendido e, também, como sendo causa, remédio, entrave ou veneno (NIETZSCHE 1998).

Desse modo, enfatizando o que foi apresentado anteriormente, Nietzsche examina os valores morais a partir de duas perspectivas, a saber: por um lado, os valores aparecem como princípios para a apreciação dos valores; por outro lado, no entanto, os valores pressupõem apreciações, supõem "'pontos de vista de apreciação' dos quais deriva o seu próprio valor" (DELEUZE 1976, p. 4). Desconfiar do valor dos valores, fazer uma interpretação dele, tendo como parâmetro unicamente a vida, é o ponto de partida para instituir um valor como sendo ou não valor. Nesse sentido, Nietzsche põe sob questionamento o valor dos valores morais e utiliza o procedimento genealógico para investigá-lo, interrogá-lo e interpretá-lo, a fim de conhecer a sua criação, as circunstâncias históricas de sua invenção e de sua efetivação enquanto valor. Nietzsche usa, portanto, o seu método genealógico para empreender uma crítica ao valor dos valores e interpretar como se deu a instituição de determinados valores como valor ao longo do tempo. Ao questionar sobre o valor dos valores e o seu estabelecimento, o procedimento genealógico nietzschiano coloca então sob desconfiança os próprios valores morais.

Dessa maneira, a genealogia de Nietzsche caracteriza-se como um instrumento de interpretação e, ao mesmo tempo, como apreciação dos valores. A apreciação é, portanto, o elemento diferencial dos valores, pois é da apreciação dos valores que provém o seu próprio valor. Nesse sentido, Deleuze define a genealogia de Nietzsche da seguinte forma:

Genealogia quer dizer ao mesmo tempo valor da origem e origem dos valores. Genealogia opõe-se ao caráter absoluto dos valores tanto quanto a seu caráter relativo ou utilitário. A genealogia significa o elemento diferencial dos valores do qual decorre o valor destes. Genealogia quer dizer, portanto, origem ou nascimento, mas também diferença ou distância na origem. Genealogia quer dizer nobreza e baixeza, nobreza e vilania, nobreza e decadência na origem. O nobre e o vil, o alto e o baixo, este é o elemento propriamente genealógico ou crítico (DELEUZE 1976, p. 5).

Os valores provêm, segundo Deleuze, dos elementos "nobre" e "vil", "alto" e "baixo", e esses elementos determinam as apreciações, pois expressam o modo de ser e de viver dos avaliadores. Nesse sentido, tais elementos não podem ser 
tomados como valores propriamente ditos, mas como elemento diferencial do qual surge o valor dos valores morais.

Para Nietzsche, foi a partir do "pathos da distância" que os "bons" mesmos, os nobres, os poderosos, os superiores em posição e pensamento em relação a tudo o que eles consideravam baixo, de pensamento baixo e vulgar, autodenominaramse bons e arrogaram para si a prerrogativa de criar valores. Os nobres sentiramse no direito de julgar e inventar valores por pensar que estavam distantes do outro e por se sentirem maiores e melhores que o outro. Segundo Nietzsche, os nobres criaram valores não por uma questão de utilidade, tampouco por sentirem compaixão pelo outro, mas tão somente por nutrirem um sentimento de superioridade em relação ao outro, o que fez com que se sentissem no direito de estipular e inventar valores. Nas palavras de Nietzsche, portanto: "Desse pathos da distância é que eles tomaram para si o direito de criar valores, cunhar nomes de valores: que lhes importava a utilidade!" (NIETZSCHE 1998, p. 19).

No entanto, tendo em vista que os valores podem se metamorfosear ao longo do tempo, o mesmo questionamento "Quem?" que se fez ao elemento genealógico nobre e que Ihe permitiu ser identificado como elemento superior que inventa valores, quando feito a outros valores, por exemplo, os valores nobres que se modificaram no decorrer do tempo, pode ser relacionado a um elemento inferior. Dessa maneira, os valores, ao serem questionados acerca da sua criação e do seu estabelecimento, podem ser provenientes tanto do elemento superior quanto do elemento inferior. Por essas indefinições e apreciações divergentes em torno da criação dos valores morais, é que a genealogia, a partir do sentimento de aproximação e distanciamento de tais valores, ocupa-se em buscar o começo do valor dos valores morais para, finalmente, examinar se a criação dos valores morais provém de uma apreciação nobre ou vil. Portanto, a dificuldade maior é identificar o que impulsiona uma determinada apreciação e qual o aspecto que define o seu valor ou não.

Dito isso, a história genealógica e afirmadora da vida, tal como a denominamos, é uma espécie de nova história dos valores morais. Como se define, então, essa nova história de Nietzsche? Eis o que, por último, nos empenharemos em demonstrar. Em primeiro lugar, acreditamos que a nova história de Nietzsche reúne elementos da história científica ${ }^{1}$ e está, ao mesmo tempo, para além dela. Ou seja, o novo modelo de história de Nietzsche não prescinde de elementos presentes na história científica, mas se nutre antes de tais elementos para se constituir. Um ponto de aproximação entre Nietzsche e a história científica, talvez, esteja dado por meio do método crítico-textual, que ambos tomam emprestado da filologia clássica. Consideramos que Nietzsche critica a história científica, mas, ao mesmo tempo, aproxima-se dela, estratégica e perigosamente, para se apoderar do método crítico-textual. Nietzsche aproxima-se da história científica porque o trabalho da filologia clássica resumese a reunir documentos antigos sobre um passado remoto, sem fazer uma leitura 
crítica deles. Inclusive Nietzsche se afasta da filologia clássica e funda uma nova filologia (filologia histórica/filologia das surpresas) por esse motivo.

Em segundo lugar, Nietzsche aproxima-se da história científica porque sabe que sem o seu auxílio não é possível fazer o questionamento da gênese dos valores morais. Nietzsche deseja, por meio do seu novo método (método genealógico/método da suspeita), fazer a crítica do valor dos valores, conhecer as condições históricas de nascimento e estabelecimento dos valores morais modernos, mas deseja também, em terceiro lugar, arriscamos dizer, estabelecer uma verdade, científica e transitória, sobre essas questões. Supomos isso, precisamente porque Nietzsche percorre o campo da moral e faz uma pesquisa científica, ele levanta documentos, ele investiga fatos, ele procura evidências que atestem o começo e o estabelecimento dos valores morais. De certa forma, ele reconstrói, com os instrumentos da própria ciência histórica, isto é, fixandose em documentos e fatos, alguma coisa que podemos chamar de "verdade". Está claro para nós que Nietzsche sabia que a sua nova genealogia da moral só teria sentido se ele permanecesse no terreno sólido da história. Ele tinha convicção que apenas com os instrumentos da ciência histórica ele conseguiria chegar até às particularidades mais concretas da moral.

Em quarto lugar, e para concluirmos este artigo, a nova abordagem da história proposta por Nietzsche, nos termos em que ele a coloca, não faz oposição entre conhecimento e vida, já que ela mesma é um tipo de saber que visa afirmar a vida em todas as circunstâncias. Insistindo na relação entre conhecimento e vida, poderíamos pensar assim mesmo: a ciência e a vida como instâncias autônomas e coexistentes. Uma precisa da outra para subsistir. A ciência não é um conhecimento em busca do semelhante e universal, nem um saber fechado, frio e meramente factual, mas um conhecimento aberto à vida diferente e singular, um saber que absorve a contingência da vida e trabalha para apreender efetivamente a sua complexidade, sem com isso deixar de ser rigoroso, sistemático e documentado. A vida aceita o favor da ciência e serve de objeto para a ciência, sem com isso deixar de ser espontânea e circunstancial.

No decurso deste artigo, a tese que pretendemos justificar é esta: Nietzsche é o criador de uma nova concepção de história, do tipo genealógico e afirmador da vida.

\section{Referências bibliográficas}

AZEREDO, Vânia Dutra de. Nietzsche e a dissolução da moral. São Paulo: Unijuí, 2000.

DELEUZE, Gilles. Nietzsche e a Filosofia. Tradução de Edmundo Fernandes Dias e Ruth Joffily Dias. Rio de Janeiro: Rio, 1976.

DENAT, Céline. A filosofia e o valor da história em Nietzsche. Uma apresentação das Considerações Extemporâneas. Cadernos Nietzsche, n. 26, p. 8596, 2010.

FONSECA, Thelma S. M. Lessa da. História e crítica na genealogia. In:

Nietzsche e a auto-superação da crítica. São Paulo: Humanitas, 2007, p. 31-87. 
FOUCAULT, Michel. Nietzsche, a genealogia e a história. In: MACHADO, Roberto (Org.). Microfísica do poder. 2. ed. São Paulo: Paz \& Terra, 2015, p. 55-86.

MACHADO, Roberto (Org.). Introdução: Arte, ciência, filosofia. In:

Nietzsche e a polêmica sobre $\mathbf{O}$ nascimento da tragédia. Tradução e notas de Pedro Süssekind. Rio de Janeiro: Jorge Zahar, 2005, p. 7-34.

MARTON, Scarlett. Foucault leitor de Nietzsche. In: Extravagâncias.

Ensaios sobre a filosofia de Nietzsche. 3. ed. São Paulo: Discurso Editoria e Barcarolla, 2009, p. 199-211.

- Genealogia da Moral: Do zelo didático aos fins estratégicos. In:

Nietzsche e a arte de decifrar enigmas - Treze conferências europeias. São Paulo: Loyola, 2014, p. 157-180.

NIETZSCHE, Friedrich. II Consideração Intempestiva: sobre a utilidade e os inconvenientes da História para a vida. In: SOBRINHO, Noéli Correia de Melo. Escritos sobre História. Rio de Janeiro: Ed. PUC-Rio; São Paulo: Loyola, 2005, p. 76-178.

. Genealogia da moral: uma polêmica. Tradução de Paulo César de Souza. São Paulo: Companhia das Letras, 1998.

Além do bem e do mal. Tradução de Paulo César de Souza. São Paulo: Companhia das Letras, 1992.

Aurora: reflexões sobre os preconceitos morais. Tradução de Mário D. Ferreira Santos. Petrópolis: Vozes, 2008.

. Ecce homo: como cheguei a ser o que sou. Tradução de Pietro Nassetti.

São Paulo: Martin Claret, 2007.

O anticristo. Tradução de Pietro Nassetti. São Paulo: Martin Claret, 2000.

PASCHOAL, Antonio Edmilson. O procedimento genealógico de Nietzsche.

Revista Diálogo Educacional, v. 1. n. 2, p. 1-21, 2000.

STEGMAIER, Werner. Depois de Montinari - Sobre a filologia-Nietzsche. In: VIESENTEINER, Jorge Luiz; GARCIA, André Luis Muniz (Org.). As linhas fundamentais do pensamento de Nietzsche: coletânea de artigos: 1985-2009. Petrópolis: Vozes, 2013, p. 287-306.

WOTLING, Patrick. A filologia como metáfora fundamental. In:

Nietzsche e o problema da civilização. Tradução de Vinícius de Andrade.

São Paulo: Barcarolla, 2013, p. 65-81. 